\title{
Ketamine and remote hyperalgesia
}

Steven B. Porter

Mayo Clinic

Eric S. Schwenk

Thomas Jefferson University

Follow this and additional works at: https://jdc.jefferson.edu/anfp

Part of the Anesthesiology Commons

Let us know how access to this document benefits you

\section{Recommended Citation}

Porter, Steven B. and Schwenk, Eric S., "Ketamine and remote hyperalgesia" (2018). Department of Anesthesiology Faculty Papers. Paper 40.

https://jdc.jefferson.edu/anfp/40

This Article is brought to you for free and open access by the Jefferson Digital Commons. The Jefferson Digital Commons is a service of Thomas Jefferson University's Center for Teaching and Learning (CTL). The Commons is a showcase for Jefferson books and journals, peer-reviewed scholarly publications, unique historical collections from the University archives, and teaching tools. The Jefferson Digital Commons allows researchers and interested readers anywhere in the world to learn about and keep up to date with Jefferson scholarship. This article has been accepted for inclusion in Department of Anesthesiology Faculty Papers by an authorized administrator of the Jefferson Digital Commons. For more information, please contact: JeffersonDigitalCommons@jefferson.edu. 
Steven B. Porter, M.D. and Eric S. Schwenk, M.D.

Ketamine and Tertiary Hyperalgesia

In the United States, the medical profession is facing the consequences of decades of reliance on opioidbased analgesia. The mainstream media has taken notice and the opioid epidemic has taken center stage in many of the nation's best-known newspapers [NYTimes]. The perioperative arena is no exception: routine elective surgery is now complicated by countless numbers of patients presenting with a history of using high doses of opioids or opioid agonist-antagonists for opioid addiction. Perioperative management of these patients is difficult and fraught with risks of under-treatment of pain due to, for example, fears of respiratory depression [Coluzzi 2017]. For example, a patient with chronic back pain secondary to failed back syndrome on methadone may present for a simple procedure such as cholecystectomy but then complain of severe back pain postoperatively. Assuming proper positioning during surgery, why would abdominal surgery exacerbate back pain?

In this issue of Minerva Anestesiologica, Moon et al. investigate the effects of ketamine, a N-methyl-Daspartate receptor (NMDA) antagonist, on pain at an area distant from the site of surgery in a randomized, placebo-controlled trial [Moon]. Surgical induction of this phenomenon, described as tertiary or remote hyperalgesia, resulted in a reduction in mechanical pain thresholds (MPT) measured at the dominant palm in healthy female patients undergoing laparoscopic hysterectomy in the control group. Moon and colleagues demonstrated that while MPT was lowered in the control group, the administration of relatively high subanesthetic doses of ketamine not only prevented a reduction in MPT but actually increased the MPT in study patients. Although they did not study pain ratings using a visual analog scale or numerical rating scale and did not report opioid consumption, these findings are encouraging because they suggest that ketamine may have a role in treating patients with baseline pain distant to the surgical site, even without a notable opioid history. They have provided some initial clinical evidence that the NMDA receptor may play a role in tertiary analgesia, although this mechanism requires further study.

The efficacy of ketamine on primary and secondary hyperalgesia have been established in a wide variety of patients and surgeries [Laskowski, Bell, Loftus, Bornemann-Cimenti]. Ketamine's analgesic mechanism of action is mostly attributed to its NMDA antagonism, although it does affect opioid and monoaminergic receptors as well [Weinbroum 2012]. Moon and colleagues speculate that ketamine's effects on tertiary hyperalgesia might be mediated through neuroplasticity via central sensitization [Moon]. They remark that the clinical relevance of the differences in MPT between the two groups of patients is currently unknown.

It is notable that the doses of ketamine used by Moon were relatively high to be considered "subanesthetic": 1 milligram (mg)/kilogram ( $\mathrm{kg}$ ) bolus followed by an infusion of $0.5 \mathrm{mg} / \mathrm{kg} / \mathrm{hour}$. Other studies of subanesthetic ketamine commonly used a $0.5 \mathrm{mg} / \mathrm{kg}$ bolus followed by an infusion of $0.15-0.5$ $\mathrm{mg} / \mathrm{kg} / \mathrm{hr}$ [Adam, Loftus, Porter, Pacreu]. Although Moon et al did not note an increase of ketaminerelated adverse side effects in their small, healthy patient population, it is well established that ketamine administered at anesthetic doses increases the incidence of untoward psychomimetic effects 
[Craven]. In a retrospective study of more than 300 postoperative patients receiving low-dose ketamine infusions, sixteen percent reported central nervous system excitation symptoms [Schwenk]. There appears to be a difference in the incidence of ketamine infusion side effects in patients undergoing general anesthesia compared to postoperative, awake patients.. However, the verdict is still out as to what dose of ketamine is both effective and devoid of side effects.

Is it possible that ketamine may be one of the answers to the clinical conundrum of patients reporting severe pain at a site considered remote and unrelated to his or her surgical trauma? If so, what is the appropriate dose of ketamine to prevent this from happening? Is there a benefit in continuing ketamine into the postoperative period? These questions currently remain unanswered, but the work of Moon and colleagues certainly brings us one step closer to effectively managing these complex clinical scenarios. We look forward to further research on this interesting topic.

Steven B. Porter, M.D.

Department of Anesthesiology and Perioperative Medicine

Mayo Clinic

4500 San Pablo Road

Jacksonville, FL 32224

Porter.steven@mayo.edu

Eric S. Schwenk, M.D.

Department of Anesthesiology

Sidney Kimmel Medical College at Thomas Jefferson University

111 South 11st Street

Philadelphia, PA 19107

Eric.schwenk@jefferson.edu

References:

"America's 8-step Program for Opioid Addiction." New York Times, September 30, 2017. https://nyti.ms/2yAfX5B; accessed 10/03/2017

Moon YE, Kim MH, Lee HM, Yoon MH, Jeon YJ. Preventative effect of ketamine on post-surgical hyperalgesia induced at a body part remote from the surgical site: A randomized controlled trial. Minerva Anestesiol (Current study)

Laskowski K, Stirling A, McKay WP, Lim HJ. A systematic review of intravenous ketamine for postoperative analgesia. Can J Anesth 2011;58;911-923. 
Bell RF, Dahl JB, Moore RA, Kalso EA. Perioperative ketamine for acute postoperative pain. Cochrane Database of Systematic Reviews 2006, Issue 1. Art. No.: CD004603. DOI:

10.1002/14651858.CD004603.pub2.

Loftus RW et al. Intraoperative ketamine reduces perioperative opiate consumption in opiatedependent patients with chronic back pain undergoing back surgery. Anesthesiology 2010;113:639-46.

Bornemann-Cimenti H, Wejbora M, Michaeli K, Edler A, Sandner-Kiesling A. The effects of minimal-dose versus low-dose S-ketamine on opioid consumption, hyperalgesia, and postoperative delirium: a tripleblinded, randomized, active- and placebo-controlled clinical trial. Minerva Anestesiol 2016;82:10691076.

Weinbroum AA. Non-opioid IV adjuvants in the perioperative period: Pharmacological and clinical aspects of ketamine and gabapentinoids. Pharm Res 2012;65:411-429.

Adam F, Chauvin M, Du Manoir B, Langlois M, Sessler DI, and Fletcher D. Small-dose ketamine infusion improves postoperative analgesia and rehabilitation after total knee arthroplasty. Anesth Analg 2005;100:475-80.

Porter SB, McClain RL, Howe BL, Ardon AE, Mazer LS, Knestrick BM, Clendenen AM. Perioperative ketamine for acute postoperative analgesia: the Mayo Clinic - Florida experience. J Perianesth Nurs 2015;30:189-95.

Pacreu S, Fernandez Candil J, Molto L, Carazo J, and Fernandez Galinski S. The perioperative combination of methadone and ketamine reduces post-operative opioid usage compared with methadone alone. Acta Anaesthesiol Scand 2012;56:1250-1256.

Craven R. Ketamine. Anaesthesia 2007;62:48-53. 